\title{
Effects of dietary Potassium Diformate on Growth Performance, Hematological and Biochemical Blood Parameters of Nile tilapia, Oreochromis niloticus L. fingerlings fed plant-based diets
}

Mona M. El-khayat ${ }^{1}$, Abd Elkarim I. M. El-Sayed ${ }^{1}$, Magdy A. Soltan ${ }^{1}$, Mohamed S. Hassaan*1 .

${ }^{1}$ Animal Production Department, Faculty of Agriculture, Benha University, Egypt.

"Corresponding Author: Mohamed.hassaan@fagr.bu.edu.eg; hassaanelhosary @ gmail.com

\begin{abstract}
A feeding trial was conducted to study the effect of dietary supplementation of potassium diformate (KDF) on $\mathrm{pH}$ of intestine, growth performance, feed utilization, hematological and serum biochemical parameters of Nile tilapia, Oreochromis niloticus (L.) fingerlings fed plant-based diets for 84 days. Three isonitrogenous $\left(310 \mathrm{~g} \mathrm{~kg}^{-1}\right.$ crude protein) and isocaloric (18.70 $\mathrm{MJ} \mathrm{kg}^{-1}$ gross energy) diets were formulated. Each diet was supplemented with $\mathrm{KDF}$ at levels; 0 (control), 5 and $10 \mathrm{~g} \mathrm{~kg}^{-1}$ diet. The results showed that the $\mathrm{pH}$ value of diet was decreased by the addition of KDF. After 84-day, the $\mathrm{pH}$ of stomach and gut was significantly decreased by supplementation of $\mathrm{KDF}$ at level $10 \mathrm{~g} \mathrm{~kg}^{-1}$ diet. The highest weight gain, specific growth rate, protein efficiency ratio and the best feed conversion ratio were recorded in fish fed either 5 or $10 \mathrm{~g} \mathrm{KDF} \mathrm{kg}^{-1}$ diet. As well, addition of KDF significantly improved hemoglobin, hematocrit, red blood cells count, white blood cells, total protein, albumin and globulin compared with the control diet. Results of this trial indicated that, the addition of KDF as feed additive enhanced the growth performance, feed utilization, hematological and blood biochemistry parameters of Nile tilapia fed diet free of fishmeal.
\end{abstract}

Keywords: Organic salt, plant protein, growth, Fish, Physiological responses.

\section{Introduction}

Aquaculture products have significantly increased in the recent years (Bostock et al., 2010). Among all, Nile tilapia has been growing rapidly in worm regions. Previous research had proven development of antibiotics resistance in bacteria of aquatic organisms also the negative effects to the environment has led to a ban of the use of such chemical substances in the field of aquaculture (Hassaan et al., 2018). Previous research stated that the use of non-chemical substances, such as acidifiers and probiotics, to increase growth performance has been performed in several fish species. Organic acids alternatives to antibiotics on the large scale and also their costeffectiveness and health benefits give them an advantage compare with antibiotics in aquafeeds (Hoseinifar et al., 2016). The most common organic acids like acetic, fumaric, and citric acid and their salts as K-diformate (KDF) and Na-diformate are used in aquaculture proven success in enhancing the growth performance and nutrients availabilities and being efficient and cost effective in various fish species. Applications of organic acids and probiotics in aquaculture are in urgent need to improve growth performance, disease resistance and increase the profitability. Organic acid salts, such as KDF, that have received attention as an alternative to antibiotics due to its easiness to handle, little or no corrosive effect and also effective against pathogenic bacteria along whole gastrointestinal tract (Castillo $\boldsymbol{e t}$ al., 2014).

Previous studies reported positive effect of inclusion graded levels of KDF affected the growth performance, feed utilization efficiency, and protein retention efficiency of Nile tilapia (Abu Elala and
Ragaa 2015). Also, Ng et al. (2009) found that supplementation of KDF at graded levels in the diets of red hybrid tilapia, Oreochromis sp significantly showed better growth performance, feed utilization efficiency and nutrient digestibility. Abu-Elala and Ragaa (2015) found that oral administration of KDF improves the feed intake efficiency of various tilapia species. Furthermore, dietary inclusion of organic acid enhances the bioavailability of minerals in rainbow trout (Oncorhynchus mykiss), sea bream (Pagrus major) and Indian carp Labeo rohita (Lückstädt 2008). Dietary acidifiers reduce the $\mathrm{pH}$ in the stomach which helps improve pepsin activity, enhancing protein digestion and absorption (Abu Elala and Ragaa, 2015). Despite the reported improvement in the nutrient availabilities of aquatic animals fed on dietary acidifiers, contradictory results have been reported on the growth promoting effects (Petkam $\boldsymbol{e t}$ al., 2008) reported no significant effect on growth performance of hybrid tilapia $(O$. niloticus $\times O$. aureus) fed on organic acids/salt blend or KDF, respectively, at various dietary levels. These contradictory results could be due to the variation of culture and rearing conditions (Vielma and Lall, 1997). Previously, few research focus on the beneficial effects of organic salts on growth performance, feed utilization and blood on aquatic organisms fed plant-based diet. Thus, the aim of this study was to evaluate the effects of dietary of KDF on growth performance, biological indices, hematological and serum biochemical parameters of Nile tilapia fed plant-bases diet for 84-day.

Materials and Methods

Experimental fish and culture technique 
Mono-sex $O$. niloticus L. male fingerlings were obtained from a private farm (El-Sahaba hatshry, Tolmbat 7, Kafr Elsheikh Governorate, Egypt). Fish were acclimated to the experimental conditions in plastic tanks $\left(0.5 \mathrm{~m}^{3}\right)$ for two weeks in the fish farm, Faculty of Agriculture, Benha University, Egypt. During the acclimation period, fish was fed a commercial diet (30\% crude protein) at a rate of $3 \%$ of biomass, which provided of equal rations at 09:00 am and 3:00 pm to adapt on the artificial diet and the trial conditions. After the acclimatization period, the experimental fish were randomly distributed into six experimental tanks $\left(0.5 \mathrm{~m}^{3}\right.$ for each $)$ representing three treatments studied. A total of 180 tilapia monosex Nile tilapia fingerlings with average initial weight of $4.29 \pm 0$. $06 \mathrm{~g}$ were used in this trial. Fish were randomly stocked with rate of 30 fish per each tank, as two tanks (replications) for each treatment. Tilapia were hand-fed with the respective diet satiation with three times daily at $09.00 \mathrm{am}, 11.00 \mathrm{am}$ and $3.00 \mathrm{pm}$. Underground water was supplied to each tank housed within a greenhouse. About one-third of water volume in each tank was daily replaced by aerated fresh water after removing the accumulated excreta. All tested water quality criteria (temperature, $\mathrm{pH}$ value, dissolved oxygen and total ammonia) were suitable and within the acceptable limits for rearing Nile tilapia O. niloticus fingerlings (Boyd, 1990).

\section{Experimental diets}

Three isonitrogenous ( $310 \mathrm{~g} \mathrm{~kg}^{-1}$ crude protein) and isocaloric (18.70 $\mathrm{MJ} \mathrm{kg}^{-1}$ gross energy) experimental diets were formulated and the proximate chemical composition of the experimental diets are presented in Table 1. The control diet contained no added KDF. Other two diets were supplemented with 5 and $10 \mathrm{~g}$ $\mathrm{KDF} \mathrm{kg}^{-1}$ diet, respectively. The ingredients were blended for 5 mins, and thoroughly mixed with soybean oil. The ingredients were mixed well and made into dry pellets using a laboratory pellet mill (A California Pellet Mill, San Francisco, CA, USA) at the National Institute of Oceanography and Fisheries, Cairo Governorate, Egypt, the temperature of pellets in this stage did not exceed $40^{\circ} \mathrm{C}$. The pellets (2-mm die) were dried for $4 \mathrm{~h}$ at opened air, and stored at $-20{ }^{\circ} \mathrm{C}$ until use. Chemical composition of the experimental diets was estimated according to the official methods (AOAC, 1995).

Table 1. Ingredients ( $\left.\mathrm{g} \mathrm{kg}^{-1} \mathrm{diet}\right)$ and proximate composition of the experimental diets (\% on dry matter basis)

\begin{tabular}{|c|c|c|c|}
\hline \multirow{2}{*}{ Ingredients } & \multicolumn{3}{|c|}{ Experimental diets } \\
\hline & Control & $5 \mathrm{~g} \mathrm{KDF} \mathrm{kg}^{-1}$ & $10 \mathrm{~g} \mathrm{KDF} \mathrm{kg}^{-1}$ \\
\hline Soybean meal (44\% CP) & 550 & 550 & 550 \\
\hline Corn gluten & 60 & 60 & 60 \\
\hline Yellow corn & 228 & 228 & 228 \\
\hline Wheat bran & 100 & 95 & 90 \\
\hline Soya oil & 40 & 40 & 40 \\
\hline Lysine & 1 & 1 & 1 \\
\hline Methionine & 1 & 1 & 1 \\
\hline Vit. \& Mine. ${ }^{1}$ & 20 & 20 & 20 \\
\hline Potassium diformate $\left(\mathrm{mg} \mathrm{kg}^{-1}\right)$ & 0 & 5 & 10 \\
\hline \multicolumn{4}{|l|}{ Chemical analysis $\%$} \\
\hline Dry matter & 89.53 & 89.54 & 89.55 \\
\hline Crude protein $(\mathrm{CP})$ & 31.40 & 31.37 & 31.30 \\
\hline Crude lipid & 5.55 & 5.53 & 5.51 \\
\hline Ash & 4.30 & 4.54 & 4.92 \\
\hline Crude fiber & 5.43 & 5.41 & 5.33 \\
\hline $\mathrm{NFE}^{2}$ & 53.32 & 53.15 & 52.94 \\
\hline Gross energy $\left(\mathrm{MJkg}^{-1}\right)^{3}$ & 18.75 & 18.71 & 18.65 \\
\hline Phytic acid $\left(\mathrm{g} \mathrm{kg}^{-1}\right)$ & 12.21 & 12.05 & 12.11 \\
\hline Trypsin inhibitor (IU mg-1 protein) & 159.20 & 158.02 & 158.80 \\
\hline \multicolumn{4}{|c|}{$\begin{array}{l}{ }^{1} \text { Each one Kg of vitamins and minerals mix. contains } \mathrm{MnSO} 4,40 \mathrm{mg} \text {; Mg O, } 10 \mathrm{mg} \text {; K2SO4, } 40 \mathrm{mg} \text {; ZnCO3, } 60 \mathrm{mg} \text {; KI, } 0.4 \mathrm{mg} \text {; } \\
\mathrm{CuSO} 4,12 \mathrm{mg} \text {; Ferric citrate, } 250 \mathrm{mg} \text {; Na2 } \mathrm{SeO} 3,0.24 \mathrm{mg} \text {; Co, } 0.2 \mathrm{mg} \text {; retinol, } 40000 \mathrm{IU} \text {; cholecalciferol, } 4000 \mathrm{IU} \text {; } \alpha \text {-tocopherol } \\
\text { acetate, } 400 \mathrm{mg} \text {; menadione, } 12 \mathrm{mg} \text {; thiamine, } 30 \mathrm{mg} \text {; riboflavin, } 40 \mathrm{mg} \text {; pyridoxine, } 30 \mathrm{mg} \text {; cyanocobalamin, } 80 \mathrm{mcg} \text {; nicotinic acid, } \\
300 \mathrm{mg} \text {; folic acid, } 10 \mathrm{mg} \text {; biotin, } 3 \mathrm{mg} \text {; pantothenic acid, } 100 \mathrm{mg} \text {; inositol, } 500 \mathrm{mg} \text {. } \\
{ }^{2} \mathrm{NFE} \text { (Nitrogen free extract) }=100 \text { - (crude protein + lipid + ash +fibre content). } \\
{ }^{3} \text { Gross energy calculated using gross calorific values of 23.63, } 39.52 \text { and } 17.15 \mathrm{KJ} \mathrm{g}^{-1} \text { for protein, fat and carbohydrate, respectively } \\
\text { according to Brett (1973). }\end{array}$} \\
\hline
\end{tabular}




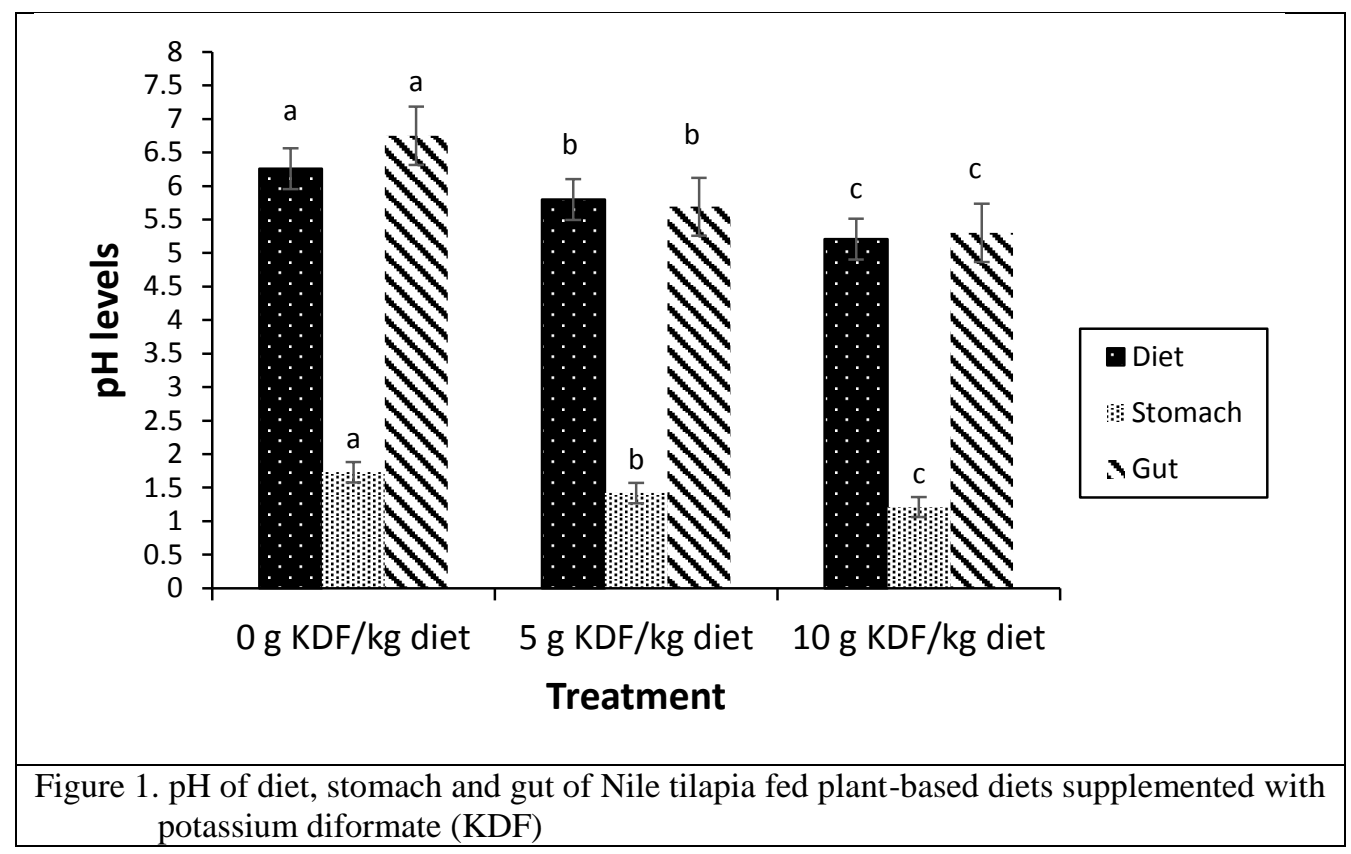

\section{Growth and feed utilization}

Records of live body weight (g) was measured in all experimental fish for each tank and registered every 14 days (two weeks) during the experimental period. Growth performance and feed utilization indices parameters were calculated by using the following equations: Weight gain $(\mathrm{WG})=$ final body weight $(\mathrm{g})$ - initial body weight $(\mathrm{g})$; specific growth rate $(\mathrm{SGR})=\mathrm{SGR}=\frac{\ln W 2-\ln W 1}{t} \times 100$, where: Where: $\mathrm{Ln}=$ the natural $\log ; \mathrm{W}_{1}=$ initial weight; $\mathrm{W}_{2}=$ the final weight in grams; $t=$ period in days. feed conversion ratio $(\mathrm{FCR})=$ feed intake $(\mathrm{g}) /$ weight gain $(\mathrm{g})$; protein efficiency ratio $(\mathrm{PER})=$ weight gain $(\mathrm{g}) /$ protein ingested (g); relative intestine length (RIL), hepatosomatic index (HSI) and spleen index (SI) were calculated using the following equations: RIL = intestine length $(\mathrm{cm}) /$ whole body weight $(\mathrm{g})$; HSI (\%) $=100 \times($ liver weight $(\mathrm{g}) /$ whole body weight $(\mathrm{g}))$ and SI $(\%)=100 \times($ spleen weight $(\mathrm{g}) /$ whole body weight $(\mathrm{g}))$.

\section{Blood sampling and hematological and biochemical indices}

At the end of the experiment, five fish $(n=5)$ were randomly selected from each tank and euthanized with tricaine methane sulfonate $1 \mathrm{~g} \mathrm{~L}^{-1}$ for 5 minutes to collect the blood samples from the caudal vein of fish in all treatments and were divided into two portions. The first portion was collected with anticoagulant $10 \%$ ethylene diamine tetraacetate (EDTA) to determine the hematocrit (Htc), hemoglobin $(\mathrm{Hb})$, red blood counts (RBCs), mean corpuscular volume (MCV), mean corpuscular hemoglobin $(\mathrm{MCH})$ and mean corpuscular hemoglobin concentration $(\mathrm{MCHC})$, and total count of white blood cells (WBCs) according to standard methods as described by Rawling et al. (2009). The second portion of the blood sample was allowed to clot at $4^{\circ} \mathrm{C}$ and centrifuged at $3000 \mathrm{rpm}$ for
$10 \mathrm{~min}$. The non-hemolyzed serum was collected and stored at $-20{ }^{\circ} \mathrm{C}$ until use for measuring the serum biochemical parameters. Levels of serum aspartate aminotransferase (AST) and alanine aminotransferase (ALT) were measured according to the method described by Reitman and Frankel (1957). Serum total protein and albumin were determined according to Henry (1964) and Wotton and Freeman (1982), respectively. However, globulin was calculated by subtracting albumin from total protein according to Coles (1974).

\section{Statistical analysis}

All collected data were statistically analyzed by using the software SAS, version 6.03 (Statistical Analysis System, 2004). The data was submitted to One-way analysis of variance (One-way ANOVA). Duncan's multiple range test was used to compare the differences between treatment means when significant $F$ values were observed (Duncan, 1955), at $P<0.05$ level.

\section{RESULTS}

pH of the diets, stomach and gut

The $\mathrm{pH}$ value of the experimental diets was lowered by the addition of KDF (Figure 1). Diet $\mathrm{pH}$ significantly $(\mathrm{P}<0.001)$ decreased from 5.97 to 5.11 with increasing dietary levels of KDF and the same trend was also observed for the stomach from 1.67 to 1.21 and gut $\mathrm{pH}$ from 6.95 to 5.55 ( $\mathrm{P}<0.05)$.

\section{Growth performance and feed utilization}

The growth performance and feed utilization of $O$. niloticus fed plant-based diet are noted in Table 2. Fish fed the diet containing $10 \mathrm{~g} \mathrm{~kg}^{-1} \mathrm{KDF}$ had the highest final body weights (FBW), WG and SGR. Feed intake in the present study significantly increased with 
increased levels of KDF. Addition of KDF to the feed also produced a better feed conversion ratio (FCR) and protein efficiency ratio (PER) than those in the diet un supplemented diet with KDF (control), more specifically in fish group fed with $10 \mathrm{KDF} \mathrm{g} \mathrm{kg}^{-1}$.

Table 2. Growth performance and feed utilization of $O$. niloticus fed plant-based diets supplemented with potassium diformate (KDF)

\begin{tabular}{lccccc}
\hline \multirow{2}{*}{ Items } & \multicolumn{3}{c}{ Treatments } & \multirow{2}{*}{ SEM } & $P$-values \\
\cline { 2 - 4 } & Control & $5 \mathrm{~g} \mathrm{KDF} \mathrm{kg}^{-1}$ & $10 \mathrm{~g} \mathrm{KDF} \mathrm{kg}^{-1}$ & & 0.236 \\
IBW $\left(\mathrm{g} \mathrm{fish}^{-1}\right)$ & 4.29 & 4.09 & 4.15 & 0.023 & 0.021 \\
FBW $\left(\mathrm{g} \mathrm{fish}^{-1}\right)$ & $21.66^{\mathrm{c}}$ & $25.73^{\mathrm{b}}$ & $28.03^{\mathrm{a}}$ & 0.526 & 0.021 \\
WG $\left(\mathrm{g} \mathrm{fish}^{-1}\right)$ & $17.38^{\mathrm{c}}$ & $21.64^{\mathrm{b}}$ & $23.88^{\mathrm{a}}$ & 0.452 & 0.035 \\
SGR & $1.93^{\mathrm{c}}$ & $2.19^{\mathrm{b}}$ & $2.27^{\mathrm{a}}$ & 0.051 & 0.232 \\
FI $\left(\mathrm{g} \mathrm{fish}^{-1}\right)$ & 44.75 & 44.51 & 45.06 & 0.231 & 0.051 \\
FCR & $2.58^{\mathrm{a}}$ & $2.06^{\mathrm{b}}$ & $1.89^{\mathrm{c}}$ & 0.035 & 0.021 \\
PER & $1.34^{\mathrm{c}}$ & $1.68^{\mathrm{b}}$ & $1.83^{\mathrm{a}}$ & 0.012 & 0.012 \\
\hline
\end{tabular}

- Values $( \pm$ SE, $n=3)$. Means in within the same row sharing the same superscript are not significantly different $(\mathrm{P}>0.05)$.

\section{Biological parameters}

Table 3 and Figure 2 showed the biological parameters; RIL, HSI and spleen index SI of Nile tilapia significantly improved the biological parameters. RIL, HSI and SI were significantly ( $\mathrm{P}<$ $0.05)$ improved by addition of KDF $\left(5 \mathrm{~g}\right.$ or $10 \mathrm{~g} \mathrm{~kg}^{-1}$ diet), which RIL and HSI were decreased and SI increased with increase the KDF levels from $5 \mathrm{~g}$ to 10 $\mathrm{g} \mathrm{kg}^{-1}$ diet. Increasing KDF levels negatively correlated with RIL; linear trend was: $\mathrm{y}=-0.039 \mathrm{x}+$ $1.7717 ; \mathrm{R}^{2}=0.9998$.

Table 3. Relative intestine length, hepatosomatic index and spleen index of $O$. niloticus fed plant-based diets supplemented with potassium diformate (KDF)

\begin{tabular}{lccccc}
\hline \multirow{2}{*}{ Items } & \multicolumn{3}{c}{ Treatments } & \multirow{2}{*}{ SEM } & \multirow{2}{*}{$P$-values } \\
\cline { 2 - 5 } & Control & $5 \mathrm{~g} \mathrm{KDF} \mathrm{kg}^{-1}$ & $10 \mathrm{~g} \mathrm{KDF} \mathrm{kg}^{-1}$ & & $1.45^{\mathrm{c}}$ \\
\hline Relative intestine length & $2.65^{\mathrm{a}}$ & $1.76^{\mathrm{b}}$ & 0.122 & 0.032 \\
Hepatosomatic index (\%) & $0.035^{\mathrm{a}}$ & $0.023^{\mathrm{b}}$ & $0.033^{\mathrm{a}}$ & 0.0001 & 0.051 \\
Spleen index (\%) & $0.002^{\mathrm{c}}$ & $0.003^{\mathrm{b}}$ & $0.005^{\mathrm{a}}$ & 0.0001 & 0.021 \\
\hline
\end{tabular}

- Values $( \pm \mathrm{SE}, \mathrm{n}=3)$. Means in within same row sharing the same superscript are not significantly different $(\mathrm{P}>$ $0.05)$.

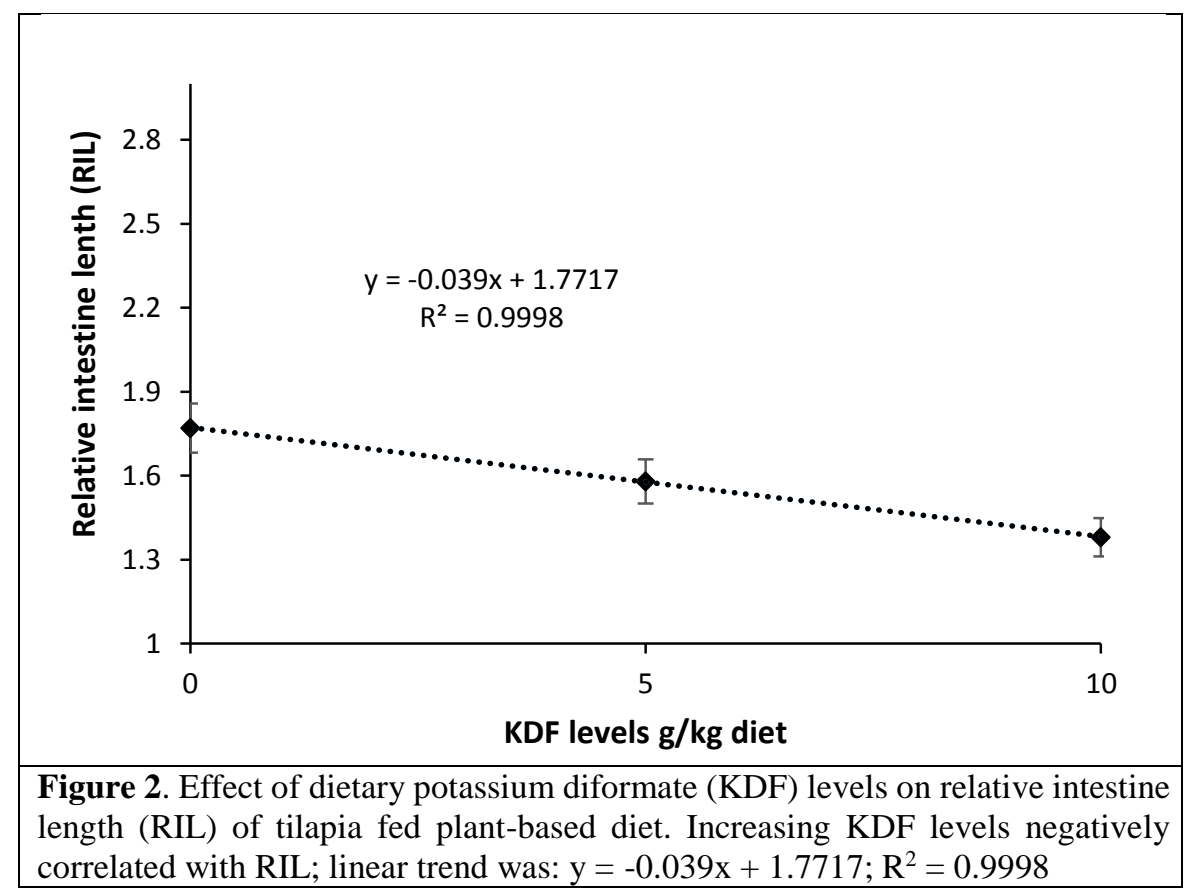




\section{Hematological parameters}

Table 4 shows that, addition of KDF in the experimental diets significantly $(\mathrm{P}<0.05)$ increased the values of $\mathrm{Hb}, \mathrm{Htc}, \mathrm{MCV}, \mathrm{MCH}, \mathrm{MCHC}, \mathrm{RBCs}$ and WBCs in the fish fed diet supplemented with KDF at graded level of 5 and $10 \mathrm{~g} \mathrm{~kg}^{-1}$ diet compared to the control group.

\section{Serum biochemical parameters}

As showed in Table 5, values of serum of ALT and (AST) total protein, albumin and globulin were significantly improved by addition different levels of KDF 5 or $10 \mathrm{~g} \mathrm{KDF} \mathrm{kg}^{-1}$ diet compared with control.

Table 4. Hematological indices of $O$. niloticus fed plant-based diets supplemented with potassium diformate (KDF)

\begin{tabular}{lccccc}
\hline \multirow{2}{*}{ Hematology } & \multicolumn{3}{c}{ Treatments } & \multirow{2}{*}{ \pm SEM } & $P$-values \\
\cline { 2 - 4 } & Control & $5 \mathrm{~g} \mathrm{KDF} \mathrm{kg}^{-1}$ & $10 \mathrm{~g} \mathrm{KDF} \mathrm{kg}^{-1}$ & & 0.0001 \\
Hemoglobin $\left(\mathrm{g} / \mathrm{dL}^{-1}\right)$ & $9.05^{\mathrm{c}}$ & $11.00^{\mathrm{b}}$ & $12.55^{\mathrm{a}}$ & 0.025 & 0.0001 \\
Hematocrit $\%$ & $16.90^{\mathrm{c}}$ & $21.45^{\mathrm{b}}$ & $25.25^{\mathrm{a}}$ & 0.285 & 0.0001 \\
MCV $(\mathrm{fl})$ & $135.00^{\mathrm{b}}$ & $142.00^{\mathrm{ab}}$ & $145.00^{\mathrm{a}}$ & 0.579 & 0.0001 \\
RBCs $\left(\times 10^{-6} \mu \mathrm{L}\right)$ & $1.29^{\mathrm{c}}$ & $1.91^{\mathrm{a}}$ & $1.85^{\mathrm{b}}$ & 0.025 & 0.0001 \\
MCH $(\mathrm{g} / \mathrm{dL})$ & $46.00^{\mathrm{c}}$ & $56.00^{\mathrm{b}}$ & $59.00^{\mathrm{a}}$ & 0.324 & 0.0001 \\
MCHC $(\mathrm{pg})$ & $31.00^{\mathrm{c}}$ & $37.00^{\mathrm{ab}}$ & $34.00^{\mathrm{b}}$ & 0.156 & 0.0001 \\
WBCs $\left(\times 10^{3} \mathrm{~mm}^{-3}\right)$ & $38.00^{\mathrm{b}}$ & $41.00^{\mathrm{a}}$ & $40.50^{\mathrm{a}}$ & 0.233 & $0.05)$. \\
\hline
\end{tabular}

- Values $( \pm$ SE, $n=3)$. Means in within same row sharing the same superscript are not significantly different $(P>0.05)$.

\section{Discussion}

Knowledge about the intestinal tract $\mathrm{pH}$ of tilapia is limited, in the present study, a decrease in the dietary $\mathrm{pH}$ was observed with increasing addition of KDF. This resulted in up to a $30.5 \% \mathrm{pH}$ decrease in the stomach digesta and a maximum reduction of $21.48 \% \mathrm{pH}$ in the gut digesta compared with the control group. The $\mathrm{pH}$ reduction in the gut digesta of tilapia fed diet supplemented with KDF was significantly low compared with the control group (Figure 1). Results of the present study are agreed with $\mathbf{N g}$ et al., (2009) who reported that diet $\mathrm{pH}$ decreased when supplemented with KDF and blend of organic acid, causing a reduction in the digesta $\mathrm{pH}$ of the stomach and gut. Similarly, Baruah et al. (2007) reported a decrease in the feed $\mathrm{pH}$ from 5.87 to 4.85 with a subsequent decrease in the $\mathrm{pH}$ of gut digesta from 6.62 to 5.65 in L. rohita fed a diet supplemented with $30 \mathrm{~g} \mathrm{~kg}^{-1}$ citric acid as compared with the control diet.

Antinutritional factors (ANFs) such phytic acid saponin which presence in the plant-based diets can reduced the utilization of nutrient of feed staff, via bind to dietary nutrients and reduce their bioavailability. Recently, organic acid or salts addition could be mitigated the adverse effects of ANFs and enhance the nutrient utilization (Soltan et al., 2017; Hassaan et al., 2018). Organic acid or salts were incorporated to diets containing high amount of plant protein with the purpose of increasing the bioavailability of nutrients and essential minerals (Baruah et al., 2007; Hassaan et al., 2014), which has been shown to have beneficial effects on growth and physiological state of fish. In the current study, all parameters of growth performance; FBW, WG and SGR of Nile tilapia fed plant protein diet were improved by addition of KDF (5 g or $10 \mathrm{~g} \mathrm{~kg}^{-1}$ diet). The improved in growth and feed utilization of fish fed plant-based diets supplemented with organic salts could be contributed to the degradation of ANFs (Hassaan et al., 2014, 2018; Soltan et al., 2017).
Also, Soltan et al., (2017) reported that tilapia fed the diet supplemented with $1 \%$ malic+oxalic acids blend showed the highest WG and SGR. Improved FCR was reported in various fish species such as Arctic charr (Salvelinus alpinus) fed diet supplemented with $1 \%$ Na-lactate (Ringø et al., 1994), Indian carp (Labeo rohita) fed citric acid (Lückstädt, 2008), Oncorhynchus mykiss fed a blend consisting of formate and sorbate (De Wet, 2005), tilapia fed potassium di-formate (Ramli et al., 2005). The present results of biological morphometric are in agreement with those of Kumar et al. (2011) who observed that relative gut length value increases as the plant protein inclusion increases from $50 \%$ and $62.5 \%$ in the common carp diets. Also, Hassaan et al. (2015) reported that the longer relative gut length of Nile tilapia fed diet containing high inclusion of plant protein, resulting in an increase in their digestion and absorption.

Hematological parameters regularly monitoring the information of physiological responses and nutritional status affecting aquatic animal (NRC, 2011). The current study showed that $\mathrm{Hb}$, Htc, RBCs and WBCs were improved in fish fed plant-based diet supplemented with KDF may be associated with decrease ANFs binding iron and amine group of amino acids which in turn lowers their availability in the blood and increases the erythrocytes (Soltan, 2005). Accordingly, the increased number of RBC multiplies the concentration of hemoglobin ultimately resulting in a higher capacity for oxygen carrying in fish. Similarly, organic acid improved hematological parameters of Juvenile beluga, Huso huso (Khajepour and Hosseini 2012); Nile tilapia (Hassaan et al., 2013) and Catla catl (Renuka et al., 2014). To date, there is no exact clarification on how organic acids or salt stimulate the hematopoietic system. 
Fish fed diets containing KDF exhibited a significant decrease in transaminases ALT and AST activity as well as improved values of total protein, albumin, and globulin compared to fish fed the control diet. Another study on Nile tilapia reported the same effect of metabolic enzymes and proteinogram when the fish were fed a diet supplemented with a blend of malic and oxalic acids at $5 \mathrm{~g} \mathrm{~kg}^{-1}$ diet (Soltan et al.,2017). Also, Hassaan et al. (2018) reported that liver functions were improved by addition of malic acid to plant diet. Albumin and globulin are essential for a healthy immune system (Tahmasebi-Kohyani et al., 2011). No data available to show the effect of organic acid or salts supplementation on biochemical blood chemistry, thus further, studies will be needed.

Table 5. Serum biochemical parameters of $O$. niloticus fed plant-based diets supplemented with potassium diformate (KDF)

\begin{tabular}{|c|c|c|c|c|c|}
\hline \multirow{2}{*}{ Items } & \multicolumn{3}{|c|}{ Treatments } & \multirow{2}{*}{ \pm SEM } & \multirow{2}{*}{$P$-values } \\
\hline & Control & $5 \mathrm{~g} \mathrm{KDF} \mathrm{kg}^{-1}$ & $10 \mathrm{~g} \mathrm{KDF} \mathrm{kg}^{-1}$ & & \\
\hline $\operatorname{ALT}(\mathrm{u} / \mathrm{L})$ & $39.00^{\mathrm{a}}$ & $34.00^{\mathrm{c}}$ & $33.00^{\mathrm{b}}$ & 1.235 & 0.001 \\
\hline $\operatorname{AST}(\mathrm{u} / \mathrm{L})$ & $11.50^{\mathrm{a}}$ & $9.50^{\mathrm{b}}$ & $9.00^{\mathrm{b}}$ & 1.19 & 0.002 \\
\hline Total protein $\left(\mathrm{u} \mathrm{dL}^{-1}\right)$ & $2.70^{c}$ & $4.15^{\mathrm{a}}$ & $4.15^{\mathrm{a}}$ & 0.230 & 0.0112 \\
\hline Albumin $\left(\mathrm{u} \mathrm{dL}^{-1}\right)$ & 1.30 & 1.70 & 1.80 & 0.031 & 0.0525 \\
\hline Globulin $\left(\mathrm{u} \mathrm{dL}^{-1}\right)$ & $1.40^{\mathrm{b}}$ & $2.45^{\mathrm{a}}$ & $2.35^{\mathrm{a}}$ & 0.045 & 0.0011 \\
\hline
\end{tabular}

- Values $( \pm \mathrm{SE}, \mathrm{N}=3)$. Means in within same row sharing the same superscript are not significantly different $(\mathrm{P}>0.05)$.

\section{References}

Abu Elala, N. M. A and Ragaa, N. M. (2015). Eubiotic effect of a dietary acidifier (potassium diformate) on the health status of cultured Oreochromis niloticus. Journal of advanced

AOAC; (1995). In: Cunni, P.A. (Ed.), Official Methods of Analysis of the Association Official Analytical Chemists, Vol. 1, 16th ed. AOAC International, Arlington, USA, p. 1298.

Baruah, K.; Pal, A. K.; Sahu, N. P.; Debnath, D.; Yengkokpam, S. and Mukherjee, S. C. (2007). Interactions of microbial phytase, citric acid and crude protein level on mineral utilization by rohu, Labeo rohita juveniles. Journal of World Aquaculture Society, 38: 238-249.

Bostock, J., McAndrew, B., Richards, R., Jauncey, K., Telfer, T., Lorenzen, K., and Corner, R. (2010). Aquaculture: global status and trends. Philosophical Transactions of the Royal Society B: Biological Sciences, 365(1554), 28972912.

Boyd, C. E. (1990). Water quality in ponds for aquaculture. Alabama Agriculture. Experiment Station, Auburn University, Alabama.

Brett, J. (1973). Energy expenditure of sockeye salmon, Oncorhynchus nerka, during sustained performance. Journal of the Fisheries Board of Canada, 30: 1799-1809.

Castillo, S; Rosales, M; Pohlenz, C and Gatlin, D. M. (2014). Effects of organic acids on growth performance and digestive enzyme activities of juvenile red drum Sciaenops ocellatus. Aquaculture 433:6-12.

https://doi.org/10.1016/j.aquaculture.

Coles, E. H. (1974). Plasma proteins. In: Veterinary clinical pathology, 2nd edition. W.B. Saunders Co., Philadelphia, Pennsylvania, USA, pp. 558-560.
De Wet, L. (2005). Organic acids as performance enhancers. Aqua Feeds: Formulation and Beyond, 2: $12-14$.

Duncan, M. B. (1955). Multiple ranges and multiple Ftests. Biometrics, 11:1-42.

Hassaan, M. S.; Soltan, M. A.; Agouz, H. M. and Badr, A. M. (2013). Influences of calcium/phosphorus ratio on supplemental microbial phytase efficiency for Nile tilapia (Oreochromis niloticus). The Egyptian Journal of Aquatic Research, 39(3): 205-213.

Hassaan, M. S., Wafa, M. A., Soltan, M. A., Goda, A. S., Mogheth, N. M. A., 2014. Effect of dietary organic salts on growth, nutrient digestibility, mineral absorption and some biochemical indices of Nile tilapia; Oreochromis niloticus L. fingerlings. World Appl. Sci. J. 29 (1), 47-55.

Hassaan, M. S.; Soltan, M. A.; and Abdel-Moez, A. M. (2015). Nutritive value of soybean meal after solid state fermentation with Saccharomyces cerevisiae for Nile tilapia, Oreochromis niloticus. Animal Feed Science and Technology, 201: 89-98.

Hassaan, M. S.; Soltan, M. A.; Mohammady, E. Y.; Elashry, M. A.; El-Haroun, E. R. and Davies, S. J. (2018). Growth and physiological responses of Nile tilapia, Oreochromis niloticus fed dietary fermented sunflower meal inoculated with Saccharomyces cerevisiae and Bacillus subtilis. Aquaculture, 495: 592-601.

Henry, R. J. (1964). Clinical Chemistry Principles and Techniques, 2nd ed. Harper and Row. Publ, New York, p. 525.

Hoseinifar, S.H; Zoheiri, F; Caipang, C.M. (2016). Dietary sodium propionate improved performance, mucosal and humoral immune responses in Caspian white fish (Rutilus frisii kutum) fry. Fish Shellfish Immunol 55:523-536. https://doi.org/10.1016/j.fsi.2016. 
Khajepour, F. and Hosseini, S. A. (2012). Citric acid improves growth performance and phosphorus digestibility in Beluga (Huso huso) fed diets where soybean meal partly replaced fish meal. Animal Feed Science and Technology, 171(1): 68-73.

Kumar, V., Makkar, H. \& Becker, K. (2011) Detoxified Jatropha curcas kernel meal as a dietary protein source: growth performance, nutrient utilization and digestive enzymes in common carp (Cyprinus carpio L.) fingerlings. Aquaculture Nutrition, 17, 313-326.

Lückstädt, C. (2008). Dietary organic acids as feed additive for tilapia (Oreochromis niloticus) culture. Program and Abstracts, $6^{\text {th }}$ Conference of the Society of Ichthyology, 13-15 March 2008, Munich, Germany; pp. 34-5.

Ng, W.K.; Koh, C.B.; Sudesh, K. and Siti-Zahrah, A. (2009). Effects of dietary organic acids on growth, nutrient digestibility and gut microflora of red hybrid tilapia, Oreochromis sp., and subsequent survival during a challenge test with Streptococcus agalactiae. Aquac. Res., 40:14901500 . https://doi.org/10.1111/j.13652109.2009.02249.x

NRC (2011): Nutrient Requirements of Fish and Shrimp. National academies press.

Petkam, R.; Luckstadt, C.; Nittayachit, P.; Sadao, S. and Encarnacao, P. (2008). Evaluation of a dietary organic acid blend on tilapia Oreochromis niloticus growth performance. Busan, Korea: World Aquaculture.

Ramli, N.; Heindl, U. and Sunanto, S. (2005). Effect of potassium-diformate on growth performance of tilapia challenged with Vibrio anguillarum. Abstract CD-Rom World Aquaculture Society, 913 May; Bali, Indonesia.

Rawling, M. D.; Merrifield, D. L. and Davies, S. J. (2009). Preliminary assessment of dietary supplementation of Sangrovit ${ }^{\circledR}$ on red tilapia (Oreochromis niloticus) growth performance and health. Aquaculture, 294:118-122.

Reitman, S. and Frankel, S. (1957). Colorimetric determination of glutamic oxaloacetic and glutamic pyruvic transaminases. Journal of Clinical Pathology, 28:56-59.

Renuka, K.; Venkateshwarlu, M. and Naik, A. R. (2014). Effect of Probiotic (Lactobacillus acidophilus) on Haematological parameters of Catla catla (Hamilton). Int. J .Curr. Microbiol. App. Sci, 3:326-335.

Ringø, E.; Olsen, R. E. and Castell, J. D. (1994). Effect of dietary lactate on growth and chemical composition of Arctic charr Salvelinus alpinus. Journal of the World Aquaculture Society, 25: 483-486.

Soltan, M. (2005). Potential of using raw and processed canola seed meal as an alternative fish meal protein source in diets for Nile tilapia (Oreochromis niloticus). Egyptian J. Nutrition and Feed. 8: 1111-1128.

Soltan, M. A.; Hassaan, M. S. and Meshrf, R. N. (2017). Response of Nile tilapia (Oreochromis niloticus) to diet acidification: effect on growth performance and feed utilization. Journal of applied aquaculture, 29(3-4): 207-219.

Tahmasebi-Kohyani, A.; Keyvanshokooh, S.; Nematollahi, A.; Mahmoudi, N. and PashaZanoosi, H. (2011). Dietary administration of nucleotides to enhance growth, humoral immune responses, and disease resistance of the rainbow trout (Oncorhynchus mykiss) fingerlings. Fish \& shellfish immunology, 30(1): 189-193.

Vielma, J. and Lall, S. P. (1997). Dietary formic acid enhances apparent digestibility of minerals in rainbow trout, Oncorhynchus mykiss (Walbaum). Aquaculture Nutrition, 3(4):265-268.

Wotton, I. D. and Freeman, H. (1982). Micro analysis in Medical Biochemistry. Churchill, New York, USA. 